\title{
„UBI TRES, ECCLESIA EST, LICET LAICI". DUCHOWIEŃSTWO A LAIKAT WE WSPÓLNOCIE KARTAGIŃSKIEJ WEDLUG TERTULIANA
}

Kościół apostolski nie oddzielał kleru od świeckich. Wielka liczba wierzących tworzyła wspólnotę ${ }^{1}$. Akcent położony jest na głęboką jedność, a nie specyfikację członków. Według Nowego Testamentu w pierwszych wspólnotach chrześcijańskich nie było żadnych rozróżnień między wierzącymi. Gmina chrześcijańska jawi się jako pewna rzeczywistość, wyróżniająca się bogatymi i różnorodnymi darami łaski, w których św. Paweł rozpoznaje formy objawienia się Ducha i dlatego nazywa je charyzmatami. Owe charyzmaty grupuje się w cztery kategorie: charyzmaty kerygmatyczne, jak posługa głoszenia, którą wykonują apostołowie, prorocy i nauczyciele; charyzmaty ekstatyczne, jak dar czynienia cudów i mówienia językami; charyzmaty organizacyjne, jak posługa organizowania i zarządzania; charyzmaty charytatywne, jak dar dawania, udzielania pomocy i świadczenia milosierdzia. To wyliczenie nie jest jednak wyczerpujące. Każdy charyzmat zobowiązywał do czynnego wkładu na rzecz wspólnoty chrześcijańskiej. Równowartość wszystkich członków wspólnoty pośród różnorodności wprowadza św. Paweł za pośrednictwem swojej koncepcji Kościoła jako Ciała Chrystusa. Wewnątrz tego ciała różnorodne członki spełniają różne funkcje, jednak żaden członek nie może wynosić się nad innych i uważać się za wyższego i bardziej wartościowego (por. 1 Kor 12, 14-25). W wewnętrznej strukturze wspólnoty nowotestamentalnej odnajdujemy także różne urzędy. We wspólnocie jerozolimskiej znajdujemy obok Apostołów, których autorytet nie podlegał zakwestionowaniu, diakonów, którzy w rzeczy-

${ }^{1}$ Por. $\mathrm{Dz}$ 4, 32: „Jeden duch i jedno serce ożywiały wszystkich wierzących. Żaden nie nazywał swoim tego, co posiadał, ale wszystko mieli wspólne”; Dz 19,18: „Przychodziło też wielu wierzących, wyznając i ujawniając swoje uczynki”; 1 Tes $1,7:$,[...] by okazać się w ten sposób wzorem dla wszystkich wierzących w Macedonii i Achai”; 1 Tes 2, 10: „Sami jesteście świadkami i Bóg także, jak zachowywaliśmy się święcie, sprawiedliwie i nienagannie pośród was wierzących"; 1 Tes 2, 13: „Dlatego nieustannie dziękujemy Bogu, bo gdy przyjęliscie słowo Boże, usłyszane od nas, przyjęliście je nie jako słowo ludzkie, ale - jak jest naprawdę - jako słowo Boga, który działa w was wierzących”; $1 \mathrm{Tm} \mathrm{4,10:} \mathrm{„Właśnie} \mathrm{o} \mathrm{to} \mathrm{trudzimy} \mathrm{się} \mathrm{i} \mathrm{walczymy,} \mathrm{ponieważ} \mathrm{złożyliśmy} \mathrm{nadzieję}$ w Bogu żywym, który jest Zbawcą wszystkich ludzi, zwłaszcza wierzących". 
wistości nie tylko zajmowali się działalnością charytatywną, ale, jak pokazuje przykład Szczepana, podejmowali się także przepowiadania. Obok Apostołów znajdują się w nich starsi i prezbiterzy. We wspólnotach zaś pochodzenia pogańskiego, przede wszystkim założonych przez św. Pawła, mówi się o przelożonych i kierownikach (1Tes 5, 12-13), o biskupach i diakonach (Flp 1, 1-2).

W nieco późniejszych pismach Nowego Testamentu znajdujemy wyraźne przypadki struktury urzędowej, zwłaszcza w liście do Efezjan, a przede wszystkim w listach pastoralnych. Tutaj urząd przyjmuje już wyraźną postać, gdyż

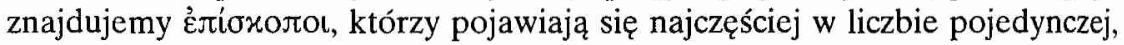

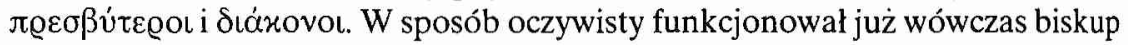
$z$ większą liczbą prezbiterów i diakonów. Już w Nowym Testamencie możemy więc stwierdzić określone struktury, co zakładało różnorodność charyzmatów i zadań. Pozwala to także na stwierdzenie, że określone funkcje, przede wszystkim funkcje kierownicze, nie tylko opierały się na charyzmatycznej spontaniczności, lecz także na określonych osobach, które wykonywały swoje zadania na mocy określonych pełnomocnictw w sposób trwały, a więc spełniały już określony urząd. Jednak to rozróżnienie wewnątrz wspólnot nie oznacza w Nowym Testamencie rozróżnienia dwóch stanów. Nie istniało bowiem jeszcze wówczas żadne zbiorowe pojęcie dla tych, którzy nie sprawowali urzędów. Pojęcie ó $\lambda \alpha o ́ \zeta$ wskazuje w Nowym Testamencie na lud Boży jako całość, oczywiście także dla oznaczenia charyzmatyków i tych, którzy sprawowali urząd - apostołów, biskupów, prezbiterów i diakonów. Także dla tych, którzy sprawowali urząd, nie było jeszcze żadnego zbiorowego pojęcia, a określenia te były płynne. Również pojęcie ó $x \lambda \tilde{n} \varrho \circ \zeta$ w nowotestamentalnym rozumieniu odnosi się nie do jakiegoś konkretnego stanu, ale do ludu Bożego jako całości. W 1P 5, 3 oznacza to słowo po prostu wspólnotę chrześcijańską ${ }^{2}$. Nigdzie nie określa się jeszcze tych, którzy sprawują urzędy pojęciem $x \lambda \hat{\eta}$ ¡o . Wszystkie pojęcia, które używamy dzisiaj dla ukazania różnorodności wewnątrz wspólnoty kościelnej, i określenia jednego stanu w przeciwieństwie do innego albo wielu innych stanów, są więc w Nowym Testamencie każdorazowo przypisane Kościołowi jako całości i wszystkim jego członkom. Określają zawsze cały lud Boży, a nigdy jakąś grupę w jego ramach ${ }^{3}$.

Słowo גaós (laicus) stosowane paralelnie ze słowem $x \lambda \tilde{n} \varrho o \varsigma$ (clerus), znajdujemy w tekstach chrześcijańskich dopiero na początku III wieku w Tradycji

${ }^{2}$ Por. 1P 5, 3: „Nie jako ci, którzy ciemięża gminy ( $\mu \eta \delta$ ' ஸ́ ale jako żywe przykłady dla stada".

${ }^{3}$ Por. J. Gaudemet, Świeccy w pierwszych wiekach Kościota, thum. L. Woroniecki, „Communio” 7 (1987) nr 39, 3-4; H.J. Klauck, Die Autorität des Charismas, w: Die Kirche der Laien, hrsg. E. Klinger - R. Zerfass, Würzburg 1987, 27-30; P. Neuner, Der Laie und das Gottes Volk, Frankfurt am Main 1988, 34-41; H. Bogacki, Charyzmatyczna struktura Kościota pierwotnego, CT 41 (1971) z. 2, 43-52. 
Apostolskiej, przypisywanej Hipolitowi Rzymskiemu, u Klemensa Aleksandryjskiego i Orygenesa, a w Afryce - u Tertuliana i Cypriana ${ }^{4}$.

We wszystkich pismach Tertuliana termin laicus występuje w sumie 15 razy w 5 jego dziełach. Termin ten w owych tekstach występuje zawsze w kontekście słów, które odnoszą się do hiẻrarchii kościelnej i kapłaństwa. Przyjrzymy się bliżej tym tekstom, by na ich podstawie ukazać, co można powiedzieć na temat struktury wewnątrz wspólnoty chrześcijańskiej w Kartaginie? Czy i jaką linię podziału w ramach wspólnoty chrześcijańskiej wytycza w nich Tertulian pomiędzy laikatem a klerem?

Analizę tych tekstów rozpoczynamy od polemicznego pisma De praescriptione haereticorum, w którym Tertulian zwalcza wszelką herezję i sposób życia wspólnot heretyckich. Jest to istotny kontekst dla wypowiedzi Tertuliana w interesującej nas kwestii, o którym nie możemy zapomnieć. W rozdziale, w którym wypowiada się na temat duchowieństwa i laikatu, autor ten przeciwstawia styl życia heretyków stylowi życia katolickiego. Zarzuca heretykom brak określonej struktury w ich wspólnotach oraz brak karności kościelnej. Swięcenia są sprawą przypadku, godność kapłańską powierza się bądź neofitom, bądź tym, którzy pochłonięci są sprawami doczesnymi; nawet kobiety ośmielają się sprawować pewne funkcje kapłańskie ${ }^{5}$. W tym kontekście Tertulian stwierdza:

„Nigdzie szybciej się tak nie awansuje, jak w obozie buntowników, gdzie już sam pobyt, uważa się za zasługę. I ćlatego dzisiaj jest ten biskupem, jutro już kto inny, dziś diakonem ten, co jutro lektorem, dziś prezbiterem ten, co jutro laikiem. Trzeba bowiem pamiętać, że i laicy u nich sprawują funkcje kapłańskie"6.

$\mathrm{W}$ analizowanym tekście słowo laicus występuje w zestawieniu $\mathrm{z}$ urzędami stanowiącymi o hierarchii kościelnej: biskupem, prezbiterem i diakonem. We wspólnotach heretyckich brak jest, według Tertuliana, ostrego podziału między hierarchią kościelną a laikatem. Każdy w każdej sytuacji może być kapłanem i sprawować funkcje kapłańskie (munera sacerdotalia). Ten tekst wskazuje więc nam, iż Tertulian opisuje wspólnotę chrześcijańską swoich czasów jako tę, która składała się z biskupa, prezbiterów, diakonów, lektorów, a także ludzi świeckich, których powinnością nie jest sprawowanie „munera sacerdotalia”.

\footnotetext{
${ }^{4}$ Por. Gaudemet, Swieccy, art. cyt., s. 3.

5 Por. P. Mattei, ,Habere ius sacerdotis". Sacerdoce et laicat au temoignage de Tertullien, RSR 59 (1985) 200-221; G. Otranto, „Nonne et laicat sacerdotes sumus”, VCh 8 (1971) 27-47; P. van Beneden, „Haben Laien die Eucharistie ohne Ordinierte gefeiert”, „Archiv für Liturgiewissenschaft" 29 (1987) 31-46; H. Wójtowicz, Terminologia kaptaniska u Tertuliana, VoxP 13-15 (19931995) z. 24-29, 77-87.

6 De praescriptionc haereticorum $41, \mathrm{CCL} 1,221-222$ : „Nusquam facilius proficitur quam in castris rebellium ubi ipsum esse illic promereri est. Itaque alius hodie episcopus, cras alius; hodie diaconus qui cras lector; hodie presbyter qui cras laicus. Nam et laicis sacerdotalia munera iniungunt", thum. E. Stanula, PSP 5, 76.
} 
Drugim pismem, w którym Tertulian mówi o podobnej strukturze wspólnoty chrześcijańskiej, jest traktat De baptismo, a dokładniej ta jego część, w której Kartagińczyk wypowiada się w kwestii szafarzy chrztu świętego. Tertulian wskazuje po pierwsze na pierwszorzędnych szafarzy:

„Prawo udzielania chrztu posiada ze swej istoty najwyższy kapłan, którym jest biskup. Następnie prezbiterzy i diakoni, jednakże nie bez upoważnienia biskupa z racji godności Kościoła. Gdy się to przestrzega utrzymuje się pokój"7?

Następnie Tertulian dodaje, kto jeszcze może być szafarzem chrztu:

..Prawo to również przysługuje i laikom, ponieważ co otrzymuje się równym prawem, równym też można przekazać; oczywiście prawo to przysługuje laikom wówczas, jeśli już nie są wezwani biskupi, prezbiterzy czy diakoni. Nauki bowiem Pana nie powinno ukrywać się przed nikim. Stąd też i chrzest jako zapis boży; może być przez wszystkich sprawowany" ${ }^{\text {"s }}$.

Po tej opinii o powszechnej możliwości udzielania chrztu przez chrześcijan Tertulian podaje jednak pewne zastrzeżenie:

„Jeśli jednak wyższym stopniom hierarchicznym nie przystoi przywłaszczać sobie funkcji biskupich, to tym bardziej laików obowiązuje prawo szacunku i skromności. Przywlaszczanie sobie funkcji biskupich jest matką schizm. «Wszystko jest dozwolone», mówi Apostol, «lecz nie wszystko jest pożyteczne» (1Kor 6, 12). Wystarczy ci oczywiście, jeśli się tym prawem posłużysz w razie konieczności, jeśli będziesz mial ku temu okazję czy to z powodu miejsca, czasu, czy osoby. Wówczas bowiem śmiałość śpieszącego na pomoc jest usprawiedliwiona, jeśli zmusza okoliczność znajdującego się w niebezpieczeństwie"9 .

Zwyczajnym szafarzem chrztu jest biskup. On jako „summus sacerdos” posiada „summum ius” do udzielania chrztu. Prezbiterzy i diakoni mogą to czynić $\mathrm{z}$ upoważnienia biskupa. Szafarzami chrztu mogą być także laici. Cały kontekst wypowiedzi Tertuliana wskazuje, że laici występują tutaj jako grupa, którą wyraźnie odróżnia się od biskupa, prezbiterów i diakonów. „Laicy” według świadectwa Tertuliana stanowią już we wspólnocie chrześcijańskiej odrębny stan. Jednak i oni mają „,ius" w zakresie szafowania chrztu świętego. „Ex aequo accipitur, aequo dari potest" - uzasadnia to uprawnienie Tertulian. Stąd można powiedzieć, że laici mają w zasadzie te same uprawnienia do udzielania chrztu co diakoni, prezbiterzy i biskup. W myśli Tertuliana laici są również kapłanami. Nieco wcześniej w tym samym traktacie De baptismo Kartagińczyk pisze:

\footnotetext{
${ }^{7}$ De baptismo 17, CCL 1, 291, thum. E. Stanula, PSP 5, 149-150.

8 Tamże, PSP 5, 150.

9 Tamże.
} 
„Po wyjściu z kąpieli chrzestnej namaszcza się nas świętym namaszczeniem. Czyni się to zgodnie $z$ dawniejszym zwyczajem, wedlug którego zwykło się namaszczać kaplanów olejem z rogu. [...] Spływa na nas olej w sposób cielesny, lecz przynoszący duchowy owoc"10.

Kapłańską godność otrzymują wszyscy chrześcijanie podczas chrztu świętego, gdy otrzymują w jego trakcie namaszczenie olejem.

Również w De oratione Tertulian wyraża przekonanie, że chrześcijanie są prawdziwymi kapłanami:

„My jesteśmy prawdziwymi czcicielami i prawdziwymi kapłanami modląc się w duchu, duchem ofiarujemy prawdziwą i miłą Bogu modlitwę oddaną Mu z całego serca, ożywioną wiarą, strzeżoną prawdą, lśniącą nienaganną niewinnością i czystością, uwieńczoną miłością, ze wspaniałością dobrych czynów, wśród psalmów i hymnów winniśmy zanieść do oltarza Pańskiego"11.

Dodajmy jeszcze do tego traktat De paenitentia, gdzie Tertulian omawiając kwestię odpuszczenia grzechów popełnionych po chrzcie świętym, mówi o zadośćuczynieniu w formie pokuty publicznej oraz modlitw, owszem prezbiterów, ale nie bez zgromadzenia wiernych ${ }^{12}$.

„Laicy” jednak powinni z uprawnienia do szafowania chrztu świętego koIzystać tylko „in necessitatibus”. Konieczność ta jest okolicznością, aby laicus skorzystał ze sprawowania funkcji kapłańskiej. Tertulian stwierdzając więc prawo wszystkich do udzielania chrztu wprowadza do niego jednak pewne ograniczenie. Na czym zaś ono się zasadza? Można powiedzieć, że chodzi tutaj o dyscyplinę i porządek w Kościele. W analizowanym przez nas tekście Afrykańczyk mówi o „disciplina verecundiae et modestiae", jaka spoczywa na laikach. Nie powinni oni rywalizować $\mathrm{z}$ wyżej postawionymi od siebie i przypisywać sobie funkcji, która w pierwszym rzędzie przynależy do biskupa (officium episcopi).

Tertulian wprowadza ponadto jeszcze jedno ograniczenie co do udzielania chrztu świętego, które odnosi się do kobiet:

„Zuchwałością zaś byłoby, gdyby kobieta przywłaszczyła sobie prawo nauczania, a tym bardziej chrzczenia, chyba żeby jakieś nowe bestie poszly w ślady pierwotnej ${ }^{13}$ do tego stopnia, że jak tamta chrzest zniszczyła, tak teraz jakaś tam przez siebie by go udzielała"14.

\footnotetext{
${ }^{10}$ Tamże 7, CCL 1, 282, PSP 5, 140.
}

1 De oratione 28, CCL 1, 273, thum. W. Kania, PSP 5, 131

12 Por. De poenitentia 9, CCL 1, 309-310, tlum. E. Stanula, PSP 5, 188-189; zob. E. Stanula, Elementy montanistyczne $w$ eklezjologii Tertuliana przed formalnym przejściem na montanizm, STV 9 (1971) nr 1, 137.

${ }^{13}$ Chodzi tutaj o Kwintyllę z Kościoła kartagińskiego, która racjonalistycznie podchodząc do sakramentu chrztu podważała jego podstawy. Przeciwko jej właśnie poglądom występuje Tertulian w traktacie De baptismo.

${ }^{14}$ De baptismo 17, CCL 1, 291, PSP 5, 150. 
Kobieta nie ma więc prawa ani nauczać, ani udzielać chrztu świętego. W tym fragmencie widoczna jest znana niechęć Tertuliana do kobiet. Ale nie chodzi tylko o to, bo stawia on kobiety poza grupą laici, skoro nie mogą nauczać i udzielać chrztu. Możemy więc wnioskować, że Afrykańczyk mówiąc o grupie laików we wspólnocie chrześcijańskiej ma na myśli przede wszystkim mężczyzn żonatych raz jeden.

Przekonuje nas o tym kolejny tekst, w którym Tertulian mówi o laikach właśnie w związku z kwestią powtórnego małżeństwa. Chodzi o tekst zawarty w De exhortatione castitatis, piśmie powstałym już w okresie, kiedy Tertulian pozostawał pod wpływem doktryny montanistycznej ${ }^{15}$. $\mathrm{Z}$ tym większym zainteresowaniem przyjrzymy się tekstowi, w którym odnosi się on do ludzi świeckich. Wyrażając sprzeciw wobec możliwości zawarcia drugiego małżeństwa Afrykańczyk przywołuje m.in. tekst św. Pawla Apostoła, że ci, którzy mają zostać biskupami bądź diakonami, powinni być mężami jednej żony (por. 1Tm 3, 2.12):

„Stąd też Apostoł pełniej i dokładniej przedstawia, że ci, którzy zostają wybrani do stanu kapłańskiego, powinni być mężami jednej żony"16.

Po przypomnieniu przykazania, które dotyczy „ordo sacerdotalis”, Tertulian dodaje następujące słowa, które kieruje do laikatu:

„Próżni będziemy, gdybyśmy uważali, że ludziom świeckim wolno jest to, czego nie wolno kapłanom. Czyż i my jako laicy nie jesteśmy kapłanami. Napisane jest «I uczynił także z nas królestwo kapłanów mających służyć Bogu i Ojcu swojemu» (Ap 1, 6). Władza Kościoła ustanowiła różnice pomiędzy stanem kapłańskim a ludem, a Bóg odbiera cześć przez uświęconą zgodność stanu kapłańskiego.

${ }^{15}$ Założycielem sekty montanistów był Montanus, prorok frygijski, który wędrując w towa. rzystwie dwóch kobiet, Maksymilli i Pryscylli, około 170 r. głosił, że ma ekstatycznie objawienia, a uważając się za Parakleta, reformował chrzescijaństwo dając mu bardziej rygorystyczne podstawy. Montanizm głosil nie tylko surową ascezę i nawoływal do życia bezgrzesznego jako warunku przygotowania na powtórne przyjście Pana i jego tysiącletniego królestwa, ale przede wszystkim rozwijał się na bazie eklezjologicznej. Nawoływal do reformy Kościoła, szczególnie do wyzwolenia się spod instytucjonalizmu kościelnego, a nawiązując do chrześcijaństwa pierwotnego, do poddania się bezpośredniemu działaniu Ducha Świętego. Właśnie przez to nawoływanie do reformy, montanizm rościl sobie pretensje, by być takim Kościołem, jakim go Chrystus chciał mieć. Montanizm idąc ze Wschodu przez Rzym powoli doszedł i do Kartaginy. Ponieważ w praktyce niewiele różnil się od religii katolickiej, więc montaniści i katolicy żyli razem, nie tworzyli oddzielnych gmin. Około 205 r. zaczęły się w gminie chrześcijańskiej debaty, zwalczania się wzajemne - aż przyszlo $w$ końcu do rozdziału. Na stronę montanistów przeszedl i Tertulian, dotąd jeden z najgorliwszych chrzescijan. Przystępując do montanistów Tertulian nie chciał zmieniać prawd wiary; chodziło mu tylko o zmianę dyscypliny kościelnej. Ale i u montanistów Tertulian nie znalazł spokoju. Niezadowolony ciągle, pełen niepokoju, zerwał z montanistami i założył wకród nich własną sektę wybranych tzw. tertulianistów, która przetrwała w Kartaginie do czasów św. Augustyna - por. J. Sajdak, Kwintus Septimiusz Florens Tertulian. Czasy - życie - dziela, Poznań 1949, 135-136; Stanula, Elementy montanistyczne, art. cyt., s. 105.

${ }^{16}$ De exhortatione castitatis 7, CCL 2, 1024, thum. K. Obrycki, PSP 29, 172. 
Kiedy nie ma zgodności kapłaństwa kościelnego, sobie samemu i składasz ofiarę i chrzcisz i jesteś kaplanem, gdzie mianowicie są trzej, jest Kościól, chociażby byliby to ludzie świeccy"17.

Tę wypowiedź Kartagińczyka, w której zgodnie z myślą zasadniczą tego pisma, argumentuje on, że również i laicy nie powinni zawierać drugiego małżeństwa, interpretuje się jako zdanie Tertuliana - montanisty, prowokującego polemisty, który popadł mimowolnie $\mathrm{w}$ niebezpieczeństwo retoryki ${ }^{18} \mathrm{i}$ w moralnej egzorcie, przeznaczonej przede wszystkim dla świeckich, znalazł sposób, by skierować strzałę przeciw duchowieństwu ${ }^{19}$. Spróbujmy jednak spokojnie przeanalizować powyższy tekst, w którym raz po raz przewijają się bardzo interesujące nas terminy, jak: „sacerdotes”, „laici”, „ordo”, „plebs”, „auctoritas Ecclesiae”.

Rozpocznijmy naszą analizę od zdania: „Differentiam inter ordinem et plebem constituit ecclesiae auctoritas, et honor per ordinis consessus sanctificatos deo". Tertulian wyraźnie odróżnia tutaj kler, który określa terminem „ordo", zapożyczonym z języka lacińskiego, stosowanym w klasyfikacji społecznej i organizacji administracyjnej ${ }^{20}$, a świeckich, których w tym przypadku określa terminem „plebs” ${ }^{21}$. Tę różnicę pomiędzy „ordo” a „laici” Tertulian uważa za pochodzącą $\mathrm{z}$ ustanowienia kościelnego (auctoritas Ecclesiae). Co jednak należy rozumieć tutaj przez decyzję Kościoła (auctoritas Ecclesiae)? Czy Tertulian chcial tu tylko podkreślić pochodzenie kościelne, a nie Boskie - tego rozróżnienia między ordo i plebs? Taki sposób rozumienia narzuca się nam w pierwszym rzędzie. Alexandre Faivre idzie jednak, moim zdaniem bardzo słusznie, w tej interpretacji jeszcze dalej, twierdząc, że Tertulian chciał w tym zdaniu podkreślić, że rozróżnienie to istniało za zgodą całego Kościoła, tj. łącznie „ordo" i „plebs”, a nie tylko na skutek decyzji hierarchii kościelnej ${ }^{22}$. Zdaje się to wynikać $\mathrm{z}$ tertuliańskiej koncepcji Kościoła, którą on ujawnia także wyraźnie w następnym zdaniu analizowanego tutaj tekstu: „Ubi ecclesiastici ordinis non est consessus, et offers et tinguis et sacerdos es tibi solus; scilicet ubi

${ }^{17}$ Tamże, CCL 2, 1024-1025: „Vani erimus, si putauerimus quod sacerdotibus non liceat laicis licere. Nonne et laici sacerdotes sumus? Scriptum est: regnum quoque nos et sacerdotes deo et patri suo fecit. Differentiam inter ordinem et plebem constituit ecclesiae auctoritas et honor per ordinis consessus sanctificatos deo. Ubi ecclesiastici ordinis non est consessus, et offers et tinguis et sacerdos es tibi solus; scilicet ubi tres, ecclesia est, licet laici", thum. K. Obrycki, PSP 29, 172-173.

${ }^{18}$ Por. A. Młotek, Kapłanistwo wiernych w nauce Ojców Kościoła, VoxP 13-14 (1993-1995) t. 24-29, 253; A. Faivre, U poczqtków laikatu, tłum. S. Wawrzkowicz, w: Laikat w Kościele katolickim. Aspekty prawno-teologiczne, Warszawa 1992, s. 24.

19 Por. Faivre, $U$ poczq̨ików laikatu, art. cyt., s. 24.

${ }^{20}$ Por. Gaudemet, Swieccy, art. cyt., s. 5.

21 „Laicus” w pismach Tertuliana ustępuje niekiedy miejsca terminowi „plebeius" (należący do plebsu, do ludu) dla oznaczenie tych, którzy nie są duchownymi, por. Gaudemet, Swieccy, art. cyt., s. 4.

${ }_{22}$ Por. Faivre, U poczq̨tón laikatu, art. cyt., s. 24. 
tres, ecclesia est, licet laici". Gdzie nie ma duchowieństwa (ecclesiastici ordinis non est consessus) człowiek świecki składa ofiarę, chrzci i sam dla siebie jest kapłanem. Dzieje się tak, ponieważ „laici” są, jak i kler, kapłanami: „Nonne et laici sacerdotes sumus"? Owi "laici” stanowią bowiem o Kościele: „ubi tres, ecclesia est, licet laici".

W tych słowach Tertulian wyraźnie nawiązuje do tekstu Mt 18, 20: „Bo gdzie są dwaj albo trzej zebrani w imię moje, tam jestem pośród nich". Do tego tekstu ewangelicznego odnosi się Tertulian także w innych swoich dziełach. W De baptismo mówiąc o skutkach chrztu stwierdza, że odpuszczenie grzechów dokonuje się w Imię Trójcy Świętej, a poszczególne osoby boskie są świadkami tego, co podczas chrztu świętego się dokonuje, poręczycielami zbawienia i naszymi sędziami ${ }^{23}$. Po tym stwierdzeniu nasz Autor z płaszczyzny sakramentalnej przechodzi na płaszczyznę eklezjologiczną i dodaje następujące słowa:

„Gdy zaś daje się w zastaw i świadectwo wiary i obietnicę zbawienia, to $\mathrm{z}$ konieczności należy uczynić wzmiankę o Kościele, ponieważ gdzie trzech, to jest Ojciec, Syn i Duch Swięty, tam i Kościół, który stanowi ciało dla tych trzech"24.

Tertulian nazywa tutaj Kościół „corpus trium”, to znaczy Ojca, Syna i Ducha Swiętego. W tekście tym widać mentalność jurysty. Przysięga złożona w obecności trzech świadków nabiera mocy prawnej. Wiara wyznana w obecności trzech świadków: Ojca, Syna i Ducha Świętego, gwarantuje otrzymanie spodziewanego daru, Ducha Świętego, a przez niego zbawienia. Potwierdzenie jednak wiary i zapewnienie zbawienia dokonuje się nie tylko w obecności trzech osób Trójcy Świętej, ale również Kościoła, który jest dla tych osób „ciałem”25.

Podobną koncepcję Kościoła jako „corpus trium” znajdujemy w piśmie $D e$ pudicitia, które powstało już po przejściu Tertuliana na montanizm, gdzie podejmuje wyraźną polemikę z Kościołem katolickim, czyli jak go określa, Kościołem psychików:

„Cóż więc odnosi się i do Kościoła, i to wprawdzie do twego, o psychiku, Kościoła? Według bowiem stanowiska Piotra ta władza będzie przysługiwać ludziom duchowym: apostołowi albo prorokowi. Albowiem i sam Kościól właściwie i zasadniczo jest samym duchem, w którym jest troistość jednego bóstwa: Ojciec i Syn i Duch Święty. Pan gromadzi taki Kościół, który oparł na trzech. A tak z kolei wszelka także liczba uczestników, którzy złączą się przy takiej właśnie wierze, będzie oceniona przez sprawcę i konsekratora jako Kościól. I dlatego Kościół wprawdzie będzie wybaczał grzechy, lecz Kościól-duch poprzez duchowego człowieka, nie zaś Kościól-liczba biskupów. Prawo i sąd należy bowiem do Pana, nie zaś do slugi; jest to zadanie Boga, nie zaś zadanie kapłana" ${ }^{26}$.

\footnotetext{
${ }^{23}$ Por. De baptismo 6, 2.

24 Tamże, CCL 1, 282, PSP 5, 140.

25 Por. Stanula, Elementy montanistyczne, art. cyt., s. 137-138.

${ }^{26}$ De pudicitia 21, 16-17, CCL 2, 1328, tłum. K. Obrycki (w rękopisie).
} 
W tym tekście Kościół według Tertuliana jawi się jako substancja duchowa, w której jest Trójca Jedynego Boga ${ }^{27}$. Ten duchowy Kościół nasz Autor przeciwstawia Kościołowi, który określa mianem „numerus episcoporum”, a który dzisiaj nazwiemy Kościołem instytucjonalnym. „Ecclesia - spiritus” jawi się tutaj jako nadrzędne wobec "Ecclesia - numerus episcoporum”. Zdaniem $\mathrm{R}$. Verstegena, oba powyższe teksty z De paenitentia i De pudicitia wyjaśniają się wzajemnie, koncentrując się na tym samym logionie, którego podstawą jest Mt 18, 20: „Bo gdzie są dwaj albo trzej zebrani w imię moje, tam jestem pośród nich"28. W tych dwóch tekstach widoczna jest też w myśli Tertuliana trynitarna koncepcja Kościoła, która w jego pismach jest czymś stałym ${ }^{29}$ tak w katolickim, jak i montanistycznym okresie twórczości.

Do tekstu Mt 18, 20 odwołuje się Tertulian także w dziele De fuga in persecutione. $\mathrm{W}$ trakcie argumentacji za zasadniczą tezą, jaką stawia w tym piśmie, że chrześcijanin nie może ani przed prześladowaniem uciekać, ani próbować się od niego wykupić, odpowiada m.in. na kontrargument tych, którzy twierdzą, że gdy chrześcijanie wykupią się od prześladowania, będą mogli bez przeszkód i spokojnie gromadzić się na liturgię. Zbijając, czasami ironicznie, ten argument dodaje:
„W ostateczności, jeżeli nie możesz gromadzić się w ciągu dnia, masz jeszcze do dyspozycji noc, którą rozświetla światło Chrystusa. Jeżeli nie możesz zgromadzić wszystkich poszczególnych wiernych, pamiętaj, że już trzy osoby stanowią Kościól. Czasami może być nawet lepiej, że nie ujrzysz zgromadzonej całej swojej wspól- noty, niż miałbyś narazić ich na niebezpieczeństwo utraty życia"30.

R. Braun określa to ujęcie Kościoła, jakie prezentuje tutaj Tertulian wzorcem Kościoła o trzech wierzących ${ }^{31}$. To samo ujęcie mamy i w naszym tekście z De exhortatione castitatis. Tertulian i tutaj ukazuje wzorzec Kościoła, który opiera się na trzech wierzących, choćby ludziach świeckich zgromadzonych w imię Chrystusa, a która to koncepcja mieści się także całkowicie w tertuliańskiej koncepcji Kościoła duchowego. W tym ujęciu Kościoła, które w sposób widoczny ujawniło się zarówno w montanistycznym okresie twórczości Tertuliana, jak i w okresie katolickim w wielu jego pismach, dla Afrykańczyka czymś o wiele istotniejszym jest sposób życia wiernych na ziemi niż społeczno-kościelna organizacja. W zasadzie najmniejsza nawet grupa ludzi, jeśli nawet są to tylko ludzie świeccy stanowi Kościół, o ile tylko posiadają oni w sobie Ducha

${ }^{27}$ Por. R. Braun, Tertullien et le montanisme: Eglise institutionnelle et Eglise spirituelle, w: Approches de Tertullien. Vingt-six études sur l'auteur et sur l'auvre, Paris 1992, 256.

${ }_{28} \mathrm{R}$. Verstegen, L'Eglise dans l'œuvre de Tertullien: pour une réinterprétation, „Bijdragen” 35 (1974) 393-410.

29 Por. Braun, Tertullien et le montanisme, art. cyt., s. 255-256.

${ }^{30}$ De fuga in persecutione 14,1, CCL 2, 1155, przeklad autora.

31 Por. Braun, Tertullien et le montanisme, art. cyt., s. 255. 
Świętego ${ }^{32}$. Z tej koncepcji Kościoła wynika także spojrzenie Tertuliana na kwestię kapłaństwa laikatu. Oni z woli Bożej są także kapłanami i mogą spełniać funkcje kapłańskie. Dla naszego Autora istotą posiadania kapłaństwa jest wiara i wypełnianie Prawa Bożego. Na te właśnie właściwości zwraca on uwage zaraz w następnym zdaniu, po tym, jak wypowiedzial słowa: „ubi tres ecclesia est, licet laici".

Laici mają więc w sobie "ius sacerdotis" ${ }^{33}$. Jednak Tertulian i w traktacie De exhortatione castitatis przewiduje, że laici z owego „ius” powinni korzystać tylko w sytuacjach koniecznych. Stwierdza bowiem:

„Jeżeli więc masz w sobie samym prawo kapłana, kiedy trzeba, to potrzeba także, ażebyś miał karność kapłańską, kiedy nie trzeba mieć prawa kapłana" ${ }^{34}$.

Funkcje kapłańskie człowiek świecki sprawuje więc, ubi necesse est. Nieco dalej Tertulian mówi wprost, iż człowiek świecki ma być zawsze przygotowany do sprawowania sakramentów w zastępstwie kapłana:

„Skoro nawet kapłana po powtórnym ożenku wylącza się od sprawowania funkcji kapłańskiej, to o ileż bardziej będzie występkiem dla człowieka świeckiego, który po raz drugi się ożenil, wykonanie w zastępstwie kapłana tego, co odnosi się do zbawienia. [...]. Bóg chce, żebyśmy wszyscy tak zostali przygotowani żeby zawsze być odpowiednimi de sprawowania jego sakramentów"35.

Analizowany przez nas siódmy rozdział De exhortatione castitatis Tertulian kończy następującymi słowami:

„Jeden Bóg, jedna wiara: jedna niech będzie i karność; aż dotąd i jeżeli ludzie świeccy nie przestrzegaliby tego, przez co dobiera się kapłanów, to w jaki sposób będą kapłanami ci, którzy z pośród świeckich są dobierani? Więc winniśmy walczyć o to, żeby naprzód polecono świeckiemu powstrzymanie śle od powtórnego małżeństwa, jak długo kaplanem nie może zostać inny człowiek świecki jak ten, który był raz jeden żonaty" ${ }^{36}$.

Ten ostatni fragment wydaje się dobrze podprowadzać nas pod ostateczny wydźwięk analizowanego tekstu. We wspólnocie chrześcijańskiej istnieją du-

32 Por. Stanula, Elementy montanistyczne, art. cyt., s. 114.

${ }^{33}$ Por. De exhortatione castitatis 7, CCL 2, 1025.

${ }^{34}$ Tamże, CCL 2, 1025: „Igitur si habes ius sacerdotis in temetipso ubi necesse est, habeas oportet etiam disciplinam sacerdotis nec ubi necesse est habere ius sacerdotis", thum. K. Obrycki, PSP 29, 173; G. Bavaud, Le laïc peut-il célébrer l'eucharistie? (Tertullien, De exhortatione castitatis VII 3) REA 42 (1996) 213-222.

35 Tamże: „quanto magis laico digamo quod ad salutem capitale erit agere pro sacerdote, cum ipsi sacerdoti digamo facto auferatur agere sacerdotem".

36 Tamże: „Unus Deus, una fides: una sit et disciplina, usque adeo nisi et laici ea obseruent, per quae presbyteri alleguntur, quomodo erunt presbyteri, qui de laicis alleguntur? ergo pugnare debemus ante laicum iussum a secundo matrimonio abstinere, dum presbyter esse non alius potest laicus quam semel fuerit maritus". 
chowni, czyli czlonkowie stanu kościelnego (ordo Ecclesiae) oraz „plebs”, „laici”, ludzie świeccy. Tym pierwszym Tertulian chce przypomnieć, że ci drudzy z woli Bożej są także kapłanami, a ponadto Autor nasz chce powiedzieć, że hierarchia kościelna pochodzi od świeckich. „Ordo Ecclesiae” zawdzięcza swoje istnienie decyzji zgromadzonego ludu. Słusznie więc wydaje się twierdzić Faivre, gdy mówi, że Tertulian udziela w tym miejscu duchowieństwu podwójnej lekcji pokory ${ }^{37}$. Wydaje mi się, że ten właśnie akcent bardziej ostrego i krytycznego spojrzenia Tertuliana na kler, odróżnia przede wszystkim dwa analizowane teksty, z De baptismo 17 i De exhortatione castitatis 7 . We wszystkim innym powyższe teksty wzajemnie się warunkują i uzupełniają.

W tym samym kluczu należy także czytać tekst Tertuliana z jego dzieła $D e$ monogamia, w którym w kwestii relacji, jaka istnieje pomiędzy duchowieństwem a laikatem, nie wnosi on żadnych nowych elementów. We wspólnocie chrześcijańskiej istnieje hierarchia kościelna (ordo Ecclesiae) oraz ludzi świeckich (laici), z których to kler bierze swój początek. Jednych i drugich obowiązuje jednożeństwo ${ }^{38}$.

Z okresu montanistycznego pochodzi kolejny tekst, z De fuga in persecutio$n e$, w którym Tertulian ukazuje wspólnotę chrześcijańską, składającą się z hierarchii kościelnej i laikatu. W kontekście zasadniczej tezy tego dzieła, że żaden chrześcijanin nie powinien uciekać przed prześladowaniem, Tertulian stwierdza:

\begin{abstract}
„Skoro ci, którym powierzono kierowanie gminą, to znaczy diakoni, prezbiterzy i biskupi uciekają, to dlaczego laik nie mógłby zrozumieć słów wypowiedzianych w ściśle określonych warunkach - uciekajcie z miasta do miasta - jako zachęty do ucieczki? Skoro więc przywódcy uciekają, czy znajdzie się jakiś szeregowiec, który przejmie dowództwo nad szykiem tych, którzy wytrwali?"39.
\end{abstract}

Po raz kolejny Tertulian ukazuje wspólnotę chrześcijańską, rozczłonkowaną na hierarchię kościelną, do której należą diakoni, prezbiterzy i biskupi, oraz na wiernych świeckich (laici); pierwsi sprawują we wspólnocie funkcje przełożeńskie (actores, duces), są pasterzami, na których spoczywa odpowiedzialność za wspólnotę; w laikach zaś dostrzega Tertulian niejako ludzi z szeregu, tych, którzy powinni mieć oparcie w swoich przywódcach. Ten militarny obraz, jaki prezentuje tutaj nasz Autor, zrozumialy jako, że pisze on w kontekście prześladowań, jakie wówczas nieustannie wspólnotom chrześcijańskim zagrażały, kryje w sobie moim zdaniem głębszy sens. Przypomnijmy sobie, iż Tertulian w De exhortatione castitatis pisal: „Unus deus, una fides, una sit et disciplina”, i przez cały okres swojego życia i twórczości był rzecznikiem dyscypliny. We wspólnocie chrześcijańskiej dostrzegał tych, którzy stoją na jej czele, a inni są

${ }^{37}$ Por. Faivre, $U$ początków laikatu, art. cyt., s. 25.

${ }^{38}$ Por. De monogamia 11, CCL 2, 1244: ,quomodo totum ordinem ecclesiae de monogamis disponit, si non haec disciplina praecedit in laicis, ex quibus ecclesiae ordo proficit?

39 De fuga in persecutione 11,1, CCL 2, 1149, przeklad autora. 
im podporządkowani. Tą pierwszą grupę stanowią, biskup, którego współpracownikami są prezbiterzy i diakoni. To na tej grupie spoczywają przede wszystkim, zarządzanie Kościołem, obowiązki pastoralne, a także „munera sacerdotalia”. „Episcopus” ma w tym względzie „summum ius”, i temu uprawnieniu Tertulian także w pismach pochodzących $\mathrm{z}$ okresu montanistycznego nigdy wyraźnie nie zaprzeczył. Drugi zaś stan, istniejacy we wspólnocie chrześcijańskiej, to „laici". Laikat Tertulian wyraźnie wyodrębnia we wspólnocie jako oddzielną grupę. Ale czy linia podziału jest już wyraźnie i ostro oznaczona? Przeprowadzona analiza odnośnych fragmentów pism Tertuliana wydaje się wskazywać, że nie. Ta linia wydaje się znajdować gdzieś wokół „munera sacerdotalia”, które raz żonaci mężczyźni, nie przynależący do „ordo Ecclesiae” mogą sprawować ,in necessitatibus”, ponieważ i oni posiadają godność kapłańską. Godność kapłańska wiernych ma więc charakter powszechny, a w pierwszym rzędzie sprawują ją we wspólnocie chrześcijańskiej przedstawiciele urzędowej hierarchii, ze względu na godność Kościoła, który opiera się na porządku i dyscyplinie. Ten porządek i dyscyplina, której brak zarzuca Tertulian heretykom, wydaje się więc stanowić o tej linii podziału, która w gruncie rzeczy jest w jego czasach dość płynna.

\section{„UBI TIRES, ECCLESIA EST, LICET LAICI”. GEISTLICHER UND LAIEN IN DER KARTHAGISCHEN GEMEINSCHAFT IN TERTULLIANS SCHRIFTEN}

\section{(Zusammenfassung)}

Tertullian war durch den ganzen Zeitraum seines Lebens und Schaffens der Sprecher der Disziplin. Er bemerkte in der christlichen Gemeinschaft diese, die leiten sie, und andere, die sind ihnen unterordnen. Bischöfe, Priester und Diakone gehören zu erster Gruppe. Die Bischöfe leiten besonders die Kirche und sie sind Seelsorger. Sie bewähren auch „,munera sacerdotalia”. Diesem Gesetz des Bischofs verleugnete Tertullian niemals deutlich. Als zweite, separate Gruppe in der christlichen Gemeinschaft spezifiziert Tertullian die Laien. „Laici”, ein mal verheiratete Männer, die zu „ordo Ecclesie” (Kirchrangordnung) nicht gehören, haben auch die priesterliche Würde. Die priesterliche Würde der Gläubigen hat der allgemeine Charakter. Die priesterliche Funktionen üben in der christlichen Gemeinschaft Bischöfe, Priester und Diakone, mit der Rücksicht auf der Disziplin und der Ordnung in der Kirche. In den notwendigen Zufällen üben es auch die Laien, das heißt die Männer. Tertullian lehnt deutlich das Gesetz der Frauen die priesterliche Funktionen auszuüben ab. Trotz der deutlichen Absonderung durch Tertullian zwei Zustände in der Kirche, ist die Linie der Aufteilung zwischen Geistlichern und Laien in den Zeiten Tertullians in dem Grund der Sache genug geläufig. 